\title{
A Reference Technique to Compare the Antimicrobial Properties of Atmospheric Pressure Plasma Sources
}

\author{
Miriam S. Mann, ${ }^{1,2, \dagger}$ Uta Schnabel,,${ }^{1,+, *}$ Thomas Weihe, ${ }^{1}$ K.-D. Weltmann, ${ }^{1}$ \& \\ Thomas von Woedtke ${ }^{1}$ \\ ${ }^{1}$ Leibniz Institute for Plasma Science and Technology, Felix-Hausdorff-Str. 2, 17489 Greifswald, \\ Germany; ' ${ }^{2}$ raunhofer Institute for Cell Therapy and Immunology IZI, 18057 Rostock, Germany \\ *Address all correspondence to: Uta Schnabel, Felix-Hausdorff-Str. 2, 17489 Greifswald, Germany. Tel. +4938345543875. \\ Fax:+493834554301. E-mail: uta.schnabel@inp-greifswald.de \\ $\dagger$ Miriam S. Mann and Uta Schnabel contributed equally to this work
}

\begin{abstract}
Medical devices need to submit stringent controls to gain a high quality standard. Therefore, international comparability has to be ensured between the laboratories or the producing industries via globally standardized assays. For medically used plasma sources, we developed a microbial assay that allows comparison of plasma sources with different designs. In the present case, test sources are an atmospheric pressure plasma jet (kINPen MED, neoplas tools $\mathrm{GmbH}$, Greifswald, Germany) and a surface dielectric barrier discharge. Beforehand, both sources were tested for their antimicrobial antimicrobial effectiveness. We normalized the data by the treated surface area and thereby defined a smallest treated unit area. Subsequently, the values were used to obtain inactivation kinetics for comparison. By normalizing the data obtained from treatment by different plasma sources we were able to compare plasma sources, independent of the treatment time. To produce an extensive overview, the assay was carried out with Escherichia coli K12 (gram-negative), Staphylococcus aureus (grampositive), and Candida albicans (yeast). The microorganisms revealed different inactivation kinetics, which offered for all tested objects the highest test stability in the stationary phase. Thus, to gain the most conclusive test data, microorganisms in the stationary phase are recommended for the assay.
\end{abstract}

KEY WORDS: non-thermal plasma sources, comparability, reference method, antimicrobial activity, Escherichia coli, Staphylococcus aureus, Candida albicans, microbial growth phases

\section{INTRODUCTION}

More than four million people in Germany suffer from chronic wounds, which require costly and intensive therapeutic efforts. ${ }^{1}$ For instance, German health insurance companies paid approximately $\$ 9.8$ billion ( 9 billion) for the therapy of diabetic people with chronic wounds in $2006 .^{2}$ These numbers clearly show that essential innovations in modern wound care system are necessary. Against this backdrop, the new and innovative research field of plasma medicine focuses on the development of atmospheric pressure plasma sources, which can be used as a medical tool. Here, the inactivation of microorganisms is the predominant mode of action to gain a therapeutic effect. Recently, the healing of skin lesions is a very promising application for such sources. ${ }^{3,4} \mathrm{~A}$ plasmabased treatment of chronic wounds enhances the proliferation of eukaryotic cells and 
therefore increases the chances that a wound will heal without commonly used targeted antibiotics, removal of nonvital tissue, attachment of antiseptic wound dressing, and immobilization of the wound area. ${ }^{5}$ In traditional wound care management the average healing duration varies between some weeks or several months. These facts lead to high hospital costs and health insurance debit.

However, the application of non-thermal plasma sources for treatment of wounds causes no tissue injury. Currently, different kinds of physical plasma sources are tested for research purposes. Numerous authors describe plasma needles, ${ }^{6}$ dielectric barrier discharges (DBD) ${ }^{7}$ helium plasma jets, ${ }^{8}$ or an atmospheric pressure plasma jet ${ }^{9}$ - a list, which can be easily enlarged. For these plasma sources, a standardized assay to determine the in-vitro antimicrobial efficiency is one of the key procedures to prove a clinical relevance. However, their effectiveness depends on their individual operating conditions such as feed gas composition, power supply, and geometrical structures. Furthermore, in terms of user-dependent microbiological techniques or used biological assays, the comparative tests globally differ. Thus, the jumble of methods exacerbates the in-vitro comparison of different plasma sources with each other. Therefore, we developed a biological and standardized reference technique to compare different atmospheric plasma sources in-vitro. For developing this general procedure, two different and well characterized atmospheric-pressure plasma sources were compared: a surface $\mathrm{DBD}^{10,11}$ and the atmospheric-pressure plasma jet kINPen, ${ }^{12}$ which is already licensed as a medical product as kINPen ${ }^{\circledR}$ MED (neoplas tools GmbH, Greifswald, Germany). ${ }^{13,14,15}$ We chose these two plasma sources because of their technical different set up. The kINPen MED ${ }^{\circledR}$ is a versatile tool for spot-like treatments of small areas, whereas the surface DBD treats bigger surfaces like a whole petri dish. In addition, surface DBD works under ambient air conditions. In contrast the kINPen ${ }^{\circledR}$ MED is usually driven with rare gases, especially argon. Also, the antimicrobial activity of these plasma sources is already shown. ${ }^{12,16,17,18,19}$ This study describes a reference protocol to compare different atmospheric pressure plasma sources in-vitro related to their antimicrobial activity. For this purpose, the antimicrobial activity was compared with three different microbial strains: Escherichia coli K12 DSM 11250 (NCTC 10538) and Staphylococcus aureus subs. aureus DSM 799 (ATCC 6538), as examples for bacterial test-strains, and Candida albicans DSM 1386 (ATCC 10231), as an example for a yeast reference-strain. These three species are representative for the entire spectrum of dermatologically relevant microorganisms. Moreover, the antimicrobial activity of the tested plasma sources was investigated in relation to typical microbial growth phases, the procedure of agar surface treatment and the subsequent evaluation method. With the described standardized reference protocol, a comparison of microbial inactivation results of different plasma sources is possible across all laboratories. 


\section{MATERIAL AND METHODS}

\section{A. Surface dielectric barrier discharge}

The nonthermal plasma of the surface DBD was ignited on the surface of an epoxide resin electrode (Figure 1, left). 11,20,21 The electrode was composed of epoxy-glass fiber bulk material ( $1.5 \mathrm{~mm}$ thick, $50 \mathrm{~mm}$ diameter), which was driven by a breakdown voltage of $40 \mathrm{kV}-\mathrm{cm}^{-1}$. The high voltage part of the surface DBD contained four concentric, ring-shaped electrodes with a width of $0.75 \mu \mathrm{m}$, which were necessary for the plasma ignition. The distance between each ring-shaped electrode was approximately $3 \mathrm{~mm}$. The electrodes were assembled from copper rings with a thickness of $35 \mu \mathrm{m}$, and they were structured by an etching process. On the other side of the dielectric, a round, flat copper surface, $35 \mathrm{~mm}$ in diameter, served as a counter electrode at ground potential. The surface DBD worked with a commercial Fourier synthesis pulse generator. In this study, ambient air conditions $\left(21^{\circ} \mathrm{C}\right.$ room temperature and a dew point of $\left.-2.45^{\circ} \mathrm{C}\right)$ and a voltage of $10 \mathrm{kV}$ peak $(20 \mathrm{kHz})$ with a $0.413 / 1.223$ second plasma-on/plasma-off time were used. The described plasma parameters were chosen because of their previously demonstrated antimicrobial effects on E. coli K12 and S. aureus in liquids. ${ }^{8,9}$ To treat inoculated agar plates, the electrode array was mounted into an upper shell of a Petri dish (60 $\mathrm{mm}$ diameter) resulting in a distance of $5 \mathrm{~mm}$ between the electrode surface and the inoculated agar in the lower shell ( $55 \mathrm{~mm}$ diameter). There was no direct contact of the plasma with the agar surface. Inoculated agar plates were treated for 10-90 seconds. The treatment area conformed to the electrode surface, because of its geometrical structure, and its corresponding size was $9.6 \mathrm{~cm}^{2}$. Because of the plane treatment using the described DBD arrangement, treatment time was independent of the treated area, as long as it did not exceed the electrode area, meaning that the same time was needed to treat both a $9.6-\mathrm{cm}^{2}$ area and a $1-\mathrm{cm}^{2}$ area.

\section{B. Atmospheric pressure plasma jet kINPen MED}

The atmospheric pressure plasma jet (APPJ) used, the kINPen MED (INP Greifswald/ neoplas tools $\mathrm{GmbH}$, Greifswald, Germany), is a commercially available plasma source. Previous studies demonstrated its antimicrobial effects on a variety of microorganisms. ${ }^{16-19}$ This plasma device consists of a handheld unit for plasma generation, a DC power supply $(60 \mathrm{~V})$, and a gas supply unit. The plasma of the APPJ was generated by a centered electrode and expanded to the surrounding air at the end of the nozzle, driven by a gas flow. This plasma-torch light was visible as a plasma jet that was $7 \mathrm{~mm}$ long and $1 \mathrm{~mm}$ wide (Figure 1, right). Argon was used as the working gas, and a gas flow of 5 standard liters per minute (SLM) was chosen. ${ }^{12-14}$ To treat the inoculated surface, the distance between the agar plates and the nozzle was set to approximately $5 \mathrm{~mm}$. Such a treatment resulted in a direct contact between the plasma and the inoculated agar plate surface. Because the APPJ is primarily most suitable for small point treatments, homogeneous treatments of larger areas could only be accomplished by moving the jet over

Volume 5, Issue 1, 2015 

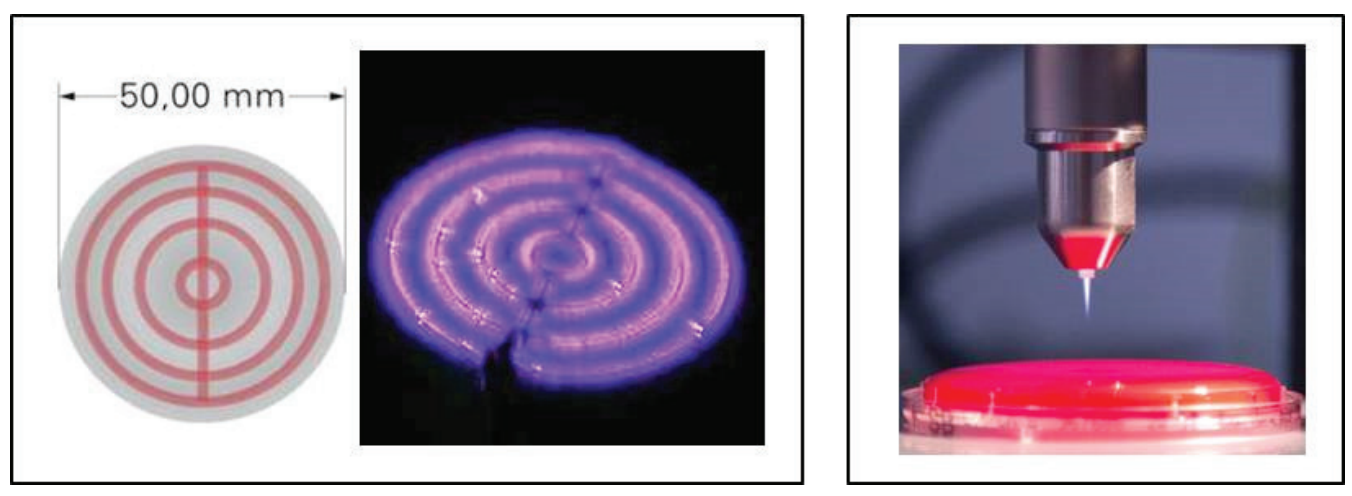

FIG. 1: Plasma ignited on the surface of DBD arrangement (left) and by the atmospheric pressure plasma jet kINPen MED (right)

the selected surface. In this particular case, the jet was moved by a computer-controlled XYZ-table using a meander-shaped pattern with $2 \mathrm{~mm}$ between the loops ${ }^{16}{ }^{16}$ this study, the diameter of this meander-shaped figure measured $37 \mathrm{~mm}$, which resulted in an overall treated area of $10.8 \mathrm{~cm}^{2}$. One meander-shaped scan process took 1 minute. One to five scans (1-5 minute treatment times) were chosen to treat the inoculated agar plates. Because of the consecutive manner of treatment by moving the plasma jet over the surface, the treatment time depended on the size of the treated area. According to the experimental conditions in our study, an area of $10.8 \mathrm{~cm}^{2}$ was treated by a 1 -minute meander-shaped scan, and the treatment of a smaller area of $1 \mathrm{~cm}^{2}$ area required 5.6 seconds.

\section{Microbial strains}

Strains used in this study are listed in Table 1. For overnight cultures, the microbial strains were cultivated in tryptic soy broth (liquid medium A [Ph.Eur. 6.0] from Carl Roth $\mathrm{GmbH} \& \mathrm{Co} . \mathrm{KG}$, Germany) under aerobic conditions at $37^{\circ} \mathrm{C}$ (bacterial strains) or at $30^{\circ} \mathrm{C}$ (yeast strain). For stock culture preparation, Columbia blood agar plates (VWR International GmbH, Germany) were used.

\section{Investigation of microorganisms}

Comparative examinations of growth behavior were conducted in $200 \mathrm{~mL}$ tryptic soy broth (liquid medium A [Ph.Eur. 6.0] from Carl Roth GmbH \& Co. KG, Germany). Batch cultures were inoculated with $10 \mathrm{vol} \%$ of overnight precultures. Afterward, batch cultures were grown under aerobic conditions at $37^{\circ} \mathrm{C}$ (bacterial strains) or at $30^{\circ} \mathrm{C}$ (yeast strain) without shaking. To determine the number of colony forming units (CFU) during the growth experiment, diluted samples of the bacterial strains or the yeast strain were plated out on tryptic soy agar (Merck, Darmstadt, Germany) or on Sabouraud 2\% glucose agar (Merck, Darmstadt, Germany), respectively. Subsequently, the agar plates 
TABLE 1: Strains used in this study

\begin{tabular}{l|l|l}
\hline Strain & Relevant Characteristic & Reference \\
\hline $\begin{array}{l}\text { Staphylococcus aureus } \\
\text { subsp. aureus ATCC 6538 } \\
\text { (DSM 799) }\end{array}$ & $\begin{array}{l}\text { Gram-positive bacteria, wild- } \\
\text { type strain }\end{array}$ & $\begin{array}{l}\text { DSMZ - German Collection } \\
\text { of Microorganisms and Cell } \\
\text { Cultures }\end{array}$ \\
\hline $\begin{array}{l}\text { Escherichia coli K12 NCTC } \\
10538 \text { (DSM 11250) }\end{array}$ & $\begin{array}{l}\text { Gram-negative bacteria, wild- } \\
\text { type strain }\end{array}$ & $\begin{array}{l}\text { DSMZ - German Collection } \\
\text { of Microorganisms and Cell } \\
\text { Cultures }\end{array}$ \\
\hline $\begin{array}{l}\text { Candida albicans ATCC } \\
10231 \text { (DSM 1386) }\end{array}$ & Yeast, wild-type strain & $\begin{array}{l}\text { DSMZ - German Collection } \\
\text { of Microorganisms and Cell } \\
\text { Cultures }\end{array}$ \\
\hline
\end{tabular}

were incubated aerobically for 24 hours at $37^{\circ} \mathrm{C}$ (bacterial strains) or for 48 hours at $30^{\circ} \mathrm{C}$ (yeast strain) to determine the number of CFUs. Growth rate and doubling time were measured to characterize growth behavior. The growth rate $(\mu)$ described the massdependent duplication of the microorganisms per hour $\left(\mathrm{x}_{1 / 2}\right.$ : measured values at time point 1 and $2 ; t_{1 / 2}$ : time point 1 and $\left.2 ; \log e=0.43429\right)$ :

$\mu=\frac{\log x_{2}-\log x_{1}}{\log e \cdot\left(t_{2}-t_{1}\right)}$

It implies that the doubling time $\left(t_{\mathrm{D}}\right)$ results from the time interval of cell mass duplication per hour $(\mu=$ growth rate; $\ln 2=0.69)$ :

$t_{D}=\frac{\ln 2}{\mu}$

\section{E. Examination of antimicrobial effectiveness of plasma sources}

To determine the antimicrobial effectiveness of plasma sources as a possible influence of microorganism growth phase, cells in two different growth phases were chosen: early exponential and early stationary growth phase. Based on the preceding growth behavior examinations, 14-16 hour cultures of E. coli and $S$. aureus and 24-26 hour cultures of C. albicans were used for the early stationary phase assay; 2-3 hour (E. coli and S. aureus) and 6-8 hour ( $C$. albicans) cultures were used for the early exponential phase assay. For the assays, suspensions of all microbial strains were diluted using physiological saline $(0.85 \% \mathrm{NaCl}[\mathrm{w} / \mathrm{v}])$ forming a stock solution with a concentration of $10^{7} \mathrm{CFU}$ per milliliter (CFU-mL ${ }^{-1}$ ). This stock solution was diluted to get less concentrated microbial suspensions for the inoculation. Agar plates (diameter of $55 \mathrm{~mm}$ filled with 5-mL agar) were inoculated with $50 \mu \mathrm{L}$ of each suspension to acquire different initial CFU per plate $\left(10^{6}\right.$ to $10^{0} \mathrm{CFU}$ per plate, corresponding to dilution steps $10^{-1}$ to $\left.10^{-7}\right)$. After a plasma treatment, the agar plates were incubated aerobically for 24 hours at $37^{\circ} \mathrm{C}$ (bacterial strains) or for 48 hours at $30^{\circ} \mathrm{C}$ (yeast strain) before colony counting.

Volume 5, Issue 1, 2015 
As mentioned previously, medically used plasma sources frequently vary in their technical setup or in their application principle. For instance, possible variations are the size of the treated area and the treatment times, as expected for the chosen sources (previously described in detail in this section) with which the experiments on agar plates were carried out. The plasma sources should be considered from that point of view.

On the one hand, and for the chosen experimental conditions, the area of a DBD treatment $\left(9.6 \mathrm{~cm}^{2}\right)$ was determined by the radius of the circular electrode. Thus, the treatment time throughout the whole treated area was the pulse length times the pulse number for every given matrix dot beneath the electrode. On the other hand, the APPJ automatically scanned a preset area of $10.8 \mathrm{~cm}^{2}$ with a thin plasma jet. Although a whole scan took 1 minute, the treatment time of each matrix dot was not determined by the total treatment time. A direct comparison of values obtained by the two sources will lead to a skewed result. The desired benchmark - the antimicrobial efficacy of different plasma sources- was hidden behind cfu counted from different area sizes and differently exposed plasma impacts. Hence, to become independent of area and time distinctions, area normalization was applied. As a consequence, the following improvements were achieved:

1. Due to the normalization of the overall treatment time, a treatment time per unit area was calculated, which allows comparisons among all tested plasma sources. Since all values were divided by the total treated area by the jet, the unit area is $1 \mathrm{~cm}^{2}$. Because of the mode of operation of the DBD, the treatment times were not normalized that way.

2. Because the total number of CFUs on the agar surfaces was normalized, an inactivation rate for both sources per unit area was calculated.

Due to these types of normalization, it was possible to achieve data of technically and/or geometrically different plasma sources, which could be transferred in inactivation kinetics per unit area $(1 \mathrm{~cm} 2)$. In this way, the antimicrobial efficacy among different plasma sources could be compared.

The upper limit of countable colonies per treated area $\left(9.6 \mathrm{~cm}^{2}\right.$ for surface DBD and $10.8 \mathrm{~cm}^{2}$ for $\mathrm{kINPen}{ }^{\circledR} \mathrm{MED}$ ) was set at $350 \mathrm{CFU}$. Because of the variation in size of treated areas, this was equal to the upper detection limit of $\sim 36 \mathrm{CFU}-\mathrm{cm}^{-2}$ for the surface DBD and of $\sim 32$ CFU- $\mathrm{cm}^{-2}$ for the kINPen MED. The lower limit of countable colonies was set at 1 CFU per treated area. This was approximated by a lower detection limit of $\sim 0.1$ CFU $-\mathrm{cm}^{-2}$ for both the surface DBD and for the kINPen MED. If the values fell below the lower detection limit, so that no colonies were countable, these values were set as $0.5 \mathrm{CFU}$ per treated area or $\sim 0.05 \mathrm{CFU}-\mathrm{cm}^{-2}$. The controls were not treated with plasma. Based on the number of viable microorganisms on untreated $\left(N_{0} ; \mathrm{CFU}-\mathrm{cm}^{-2}\right)$ and countable plasma-treated samples $\left(N_{a} ; \mathrm{CFU}-\mathrm{cm}^{-2}\right)$, the logarithmic reduction factors $(\lg \mathrm{R})$ were calculated:

$\lg R=\lg N_{0}-\lg N_{a}$ 


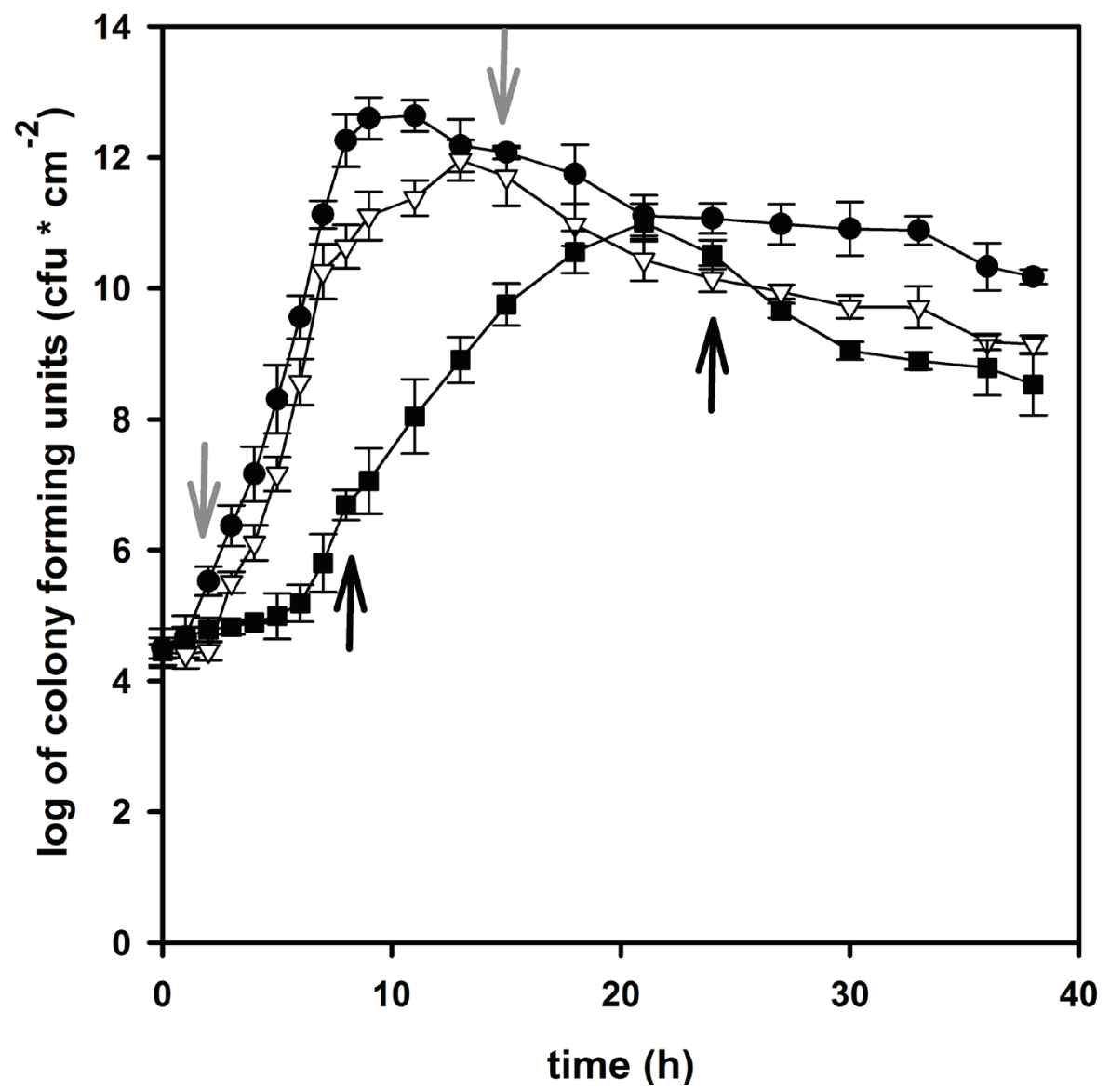

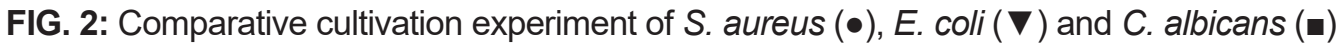

Semi-logarithmic plots were chosen as graphical presentation for inactivation kinetics of microorganisms.

\section{RESULTS}

\section{A. Growth behavior}

To determine the typical growth patterns of the bacterial and yeast test strains, cultivation experiments in tryptic soy broth were performed.

Cultivations were conducted in $200 \mathrm{ml}$ tryptic soy bouillon, samples were regularly drawn to determine colony forming units. Arrows mark the time points of growth state where the samples for plasma treatment experiments were taken (grey: E. coli and S. aureus; black: C. albicans). Average data of two independent replicates per strain were used. 
All three microbial test strains showed a typical bacterial or yeast growth curve with different phases of growth. In all three cases, the short lag phase varied depending on the microbial test strain. The bacterial strains needed 3-4 hours to pass through the lag phase. In contrast, the yeast strain needed 6-7 hours to complete the lag phase. For all examined cases, the lag phase was followed by an exponential growth phase. This phase was characterized by a rapid increase in CFUs. For E. coli K-12 and S. aureus, the number of CFUs increased by $8 \log _{10}$ within 5 hours. C. albicans needed 10 hours to reach the maximum of $10 \log _{10}$ of CFUs. After a growth maximum had been achieved, all tested microbial strains reached their stationary growth phase. Summarizing the data just presented, the growth rate of $C$. albicans was much slower than that of the bacterial test strains. C. albicans needed 5-6 hours more to reach and pass through each growth phase. Accordingly, C. albicans showed a twofold higher doubling time (44 minutes) and a significantly slower growth rate than E. coli or $S$. aureus (see appendix, Table 2).

\section{B. Plasma inactivation of viable microorganisms}

In this study, the surface DBD and the APPJ were analyzed for their antimicrobial efficiency in order to develop a reference technique for comparing different plasma sources. These two plasma sources were chosen because of the differences in their surface treatment methods. The DBD treats the area en bloc, whereas the APPJ only treats a spot on the surface.

Figures 3 to 5 show the inactivation of three different microbial strains (E. coli K-12, $S$. aureus, and C. albicans). For all three strains, the inactivation profiles, including the exponential and the stationary growth phase, were determined. Hence, the diagrams accentuate the inactivation differences of each strain, which occurred in their different growth phases - the exponential and stationary growth phases. As described earlier, the upper and lower detection limits were introduced in all diagrams.

Figure 3 shows the inactivation kinetics of the gram-negative bacterium $E$. coli K-12 treated with surface DBD (Figure 3, A and B) and the kINPen MED (Figure 3, $\mathrm{C}$ and $\mathrm{D})$. By comparing the values of the exponential (Figure 3A) and the stationary (Figure 3B) growth phases of E. coli $\mathrm{K}-12$, a difference in inactivation kinetics is visible. After a $30 \mathrm{sec}-\mathrm{cm}^{-2}$ plasma treatment, no more viable microorganisms were detectable for exponentially grown cells (Figure 3A). This corresponds to a reduction factor of up to $6 \log _{10}$ per $\mathrm{cm}^{-2}$ within 30 seconds, which also depended on the initial concentration. In contrast, after a $30 \mathrm{sec}-\mathrm{cm}^{-2}$ treatment for stationary grown cells, a reduction of only approximately $3 \log _{10}$ per $\mathrm{cm}^{2}$ was obtained, which was independent

TABLE 2: Physiological parameters from S. aureus, E. coli K-12, and C. albicans

\begin{tabular}{l|l|l|l}
\hline Parameter & S. aureus & E. coli K12 & C. albicans \\
\hline Growth rate $(\mu)$ & 3.11 & 3.31 & 1.57 \\
\hline Doubling time $(\mathrm{tD})$ & $22 \mathrm{~min}$ & $21 \mathrm{~min}$ & $44 \mathrm{~min}$ \\
\hline
\end{tabular}




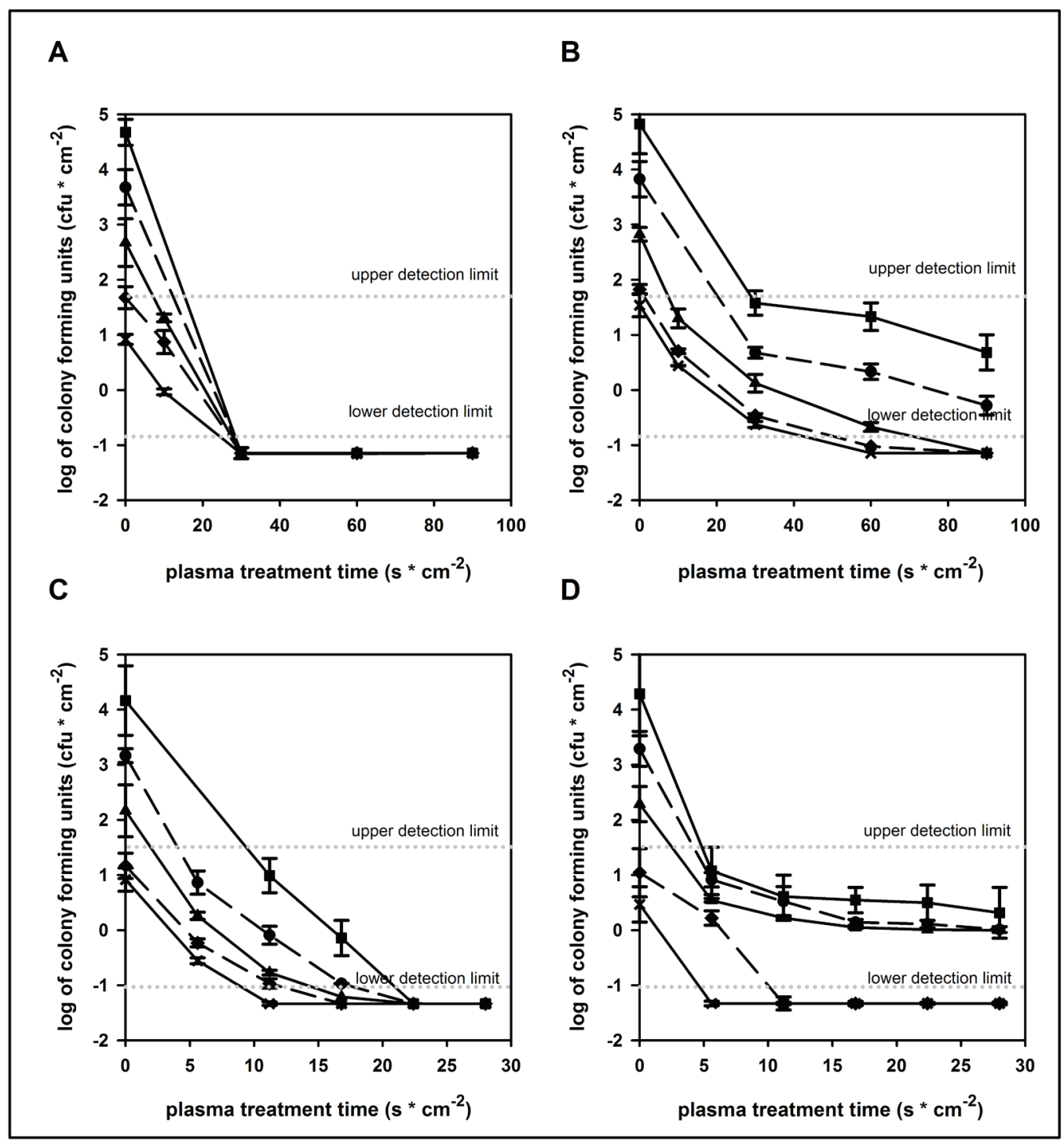

FIG. 3: Inactivation kinetics of $E$. coli on agar plates as a result of different plasma treatments. (A) Exponentially grown E. coli treated with surface DBD. (B) Stationary grown E. coli treated with surface DBD. (C) Exponentially grown E. coli treated with kINPen MED. (D) Stationary grown E. coli treated with kINPen MED. Average data of three independent tests were used

of the initial concentration of microorganisms in all cases (Figure 3B). Subsequently, for longer treatments ( $>30$ seconds), flatter inactivation kinetics were found. Kinetics were not dependent on starting concentration. When higher initial concentrations were tested 
with a treatment of $90 \mathrm{sec}-\mathrm{cm}^{-2}$, an increase in survival was observed. In general, similar reduction factors of about $5 \log _{10}$ steps had been achieved within a 90 -second treatment time of stationary grown $E$. coli $\mathrm{K}-12$ with surface DBD.

Comparing the results from exponential (Figure 3C) and stationary (Figure 3D) growth phases of E. coli $\mathrm{K}-12$ cells treated with the kINPen MED, a difference in inactivation kinetics was likewise visible. In the case of exponentially grown cells, more or less linear inactivation kinetics had been found (Figure 3C). Similar reductions of 1.5-2 $\log _{10}$ per $\mathrm{cm}^{2}$ were found after a treatment time of $5.6 \mathrm{sec}-\mathrm{cm}^{-2}$. Depending on the initial concentration, the number of surviving microorganisms fell below the lower detection limit after treatment times between 11.2 and $22.4 \mathrm{sec}-\mathrm{cm}^{-2}$. After $22.4 \mathrm{sec}-\mathrm{cm}^{-2}$ treatment time, no more viable cells were detected in all cases. This result was comparable to the latter one found for the surface DBD with exponentially grown E. coli (see Figure 3A). Similar to surface DBD treatment (see Figure 3B), a kINPen MED treatment of stationary growth phase cells revealed biphasic inactivation kinetics (Figure 3D). A reduction of 1.5-3 $\log _{10}$ per $\mathrm{cm}^{2}$ for a treatment time of $5.6 \mathrm{sec}-\mathrm{cm}^{-2}$ was observed. Particularly, the experiments using higher initial concentrations revealed a flattening of the inactivation kinetics for longer treatment times, meaning that no additional bacterial inactivation was observed. About $1 \mathrm{CFU}-\mathrm{cm}^{-2}$ viable cells was left after $28 \mathrm{sec}-\mathrm{cm}^{-2}$ treatment time. Only in two cases using lower initial concentrations, the number of viable microorganisms fell below the lower detection limit after a 5.6 and a $11.2 \mathrm{sec}-\mathrm{cm}^{-2}$ treatment time.

In the next test series, inactivation kinetics of the gram-positive bacterium $S$. aureus were observed (Figure 4). Figure 4A showed an inactivation of exponentially grown $S$. aureus by a surface DBD. In summary, a reduction of $2-4.5 \log _{10}$ per $\mathrm{cm}^{2}$ was obtained. Unless the highest initial concentration was used, the number of viable cells fell below detection limits after a 5-60 sec- $\mathrm{cm}^{-2}$ treatment time. Generally, surface DBD treatment of stationary grown $S$. aureus (Figure 4B) resulted in a slightly lower inactivation effect. This difference was similar to the latter one found for E. coli K-12 (Figure 3, $\mathrm{A}$ and $\mathrm{B}$ ). Only in two test series using low initial concentrations, no surviving bacteria had been found after a 5 or a $60 \mathrm{sec}-\mathrm{cm}^{-2}$ treatment time. If higher initial concentrations were used, biphasic inactivation kinetics was detected, which resulted in surviving microorganisms even after a $90 \mathrm{sec}-\mathrm{cm}^{-2}$ treatment time.

Using kINPen MED, the exponentially grown S. aureus (Figure 4C) had repeatedly been found more susceptible compared to stationary grown ones. Using lower initial concentrations, the number of viable cells fell below the detection limit after an 11.2 and a $22.4 \mathrm{sec}-\mathrm{cm}^{-2}$ treatment time. For higher initial concentrations, a decrease of viable microorganisms for 1.5-3 $\log _{10}$ per $\mathrm{cm}^{2}$ was observed for treatments of $11.2 \mathrm{sec}-\mathrm{cm}^{-2}$ or less. Subsequently, the number of viable bacteria remained more or less stable, which appeared at approximately $50 \mathrm{CFU}-\mathrm{cm}^{-2}$ and treatment times up to $28 \mathrm{sec}-\mathrm{cm}^{-2}$. Treating stationary grown $S$. aureus with the kINPen MED (Figure 4D), the number of viable microorganisms did not fall below detection limits in any case. Dependent on the initial concentration, reductions up to $2.5 \log$ per $\mathrm{cm}^{2}$ resulted from a maximum treatment time of $28 \mathrm{sec}-\mathrm{cm}^{-2}$. 


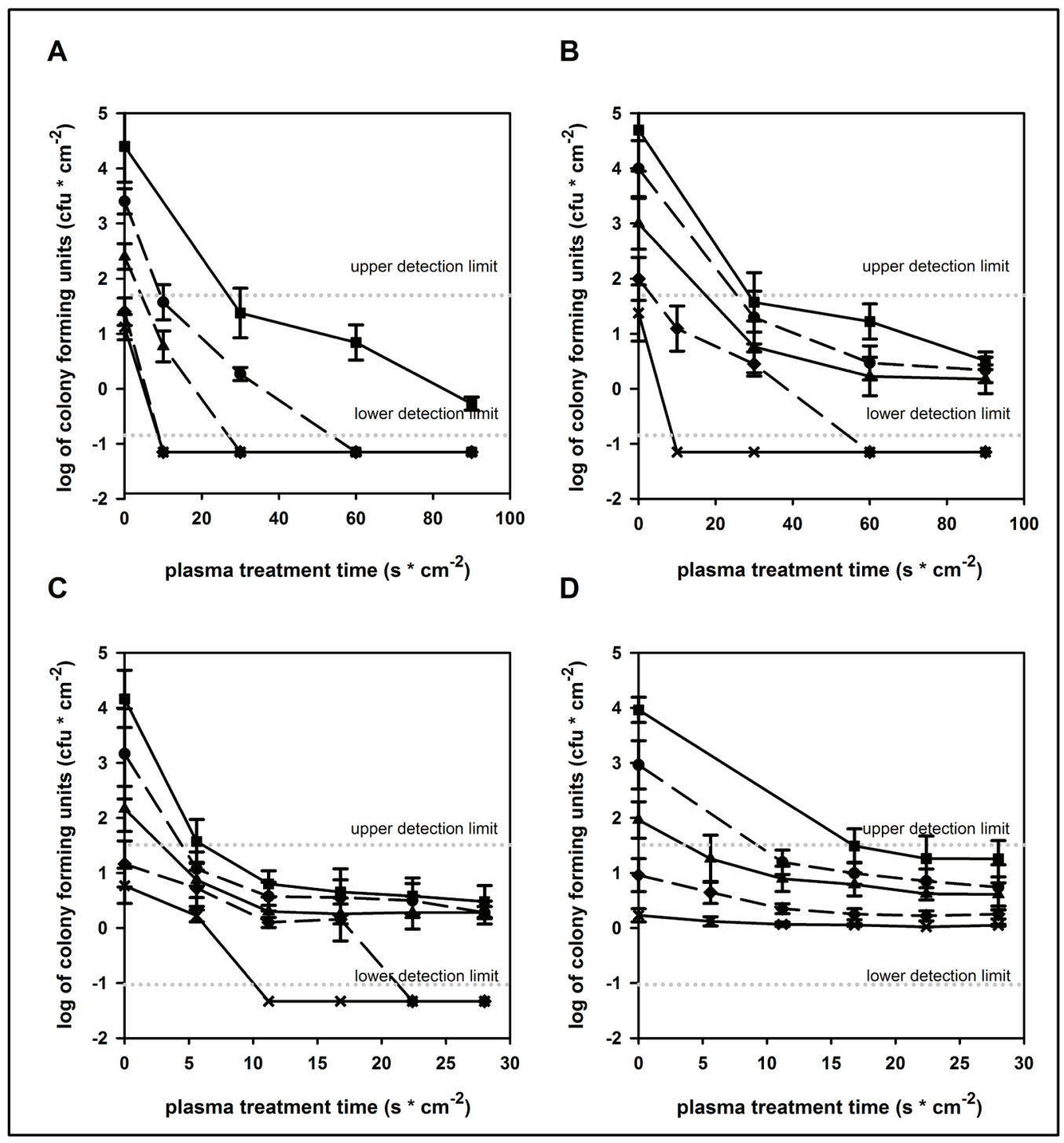

FIG. 4: Inactivation kinetics of $S$. aureus on agar plates as a result of different plasma treatments. (A) Exponentially grown $S$. aureus treated with surface DBD. (B) Stationary grown $S$. aureus treated with surface DBD. (C) Exponentially grown $S$. aureus treated with kINPen ${ }^{\circledR}$ MED. (D) Stationary grown S. aureus treated with kINPen MED. Average data of three independent tests were used.

To complete the entire spectrum of microorganisms, the yeast strain C. albicans was also tested (Figure 5). The treatment of exponentially grown $C$. albicans (Fig. 5A) with a surface DBD caused a rapid decrease of viable cells. After a treatment time of $30 \mathrm{sec}-\mathrm{cm}^{-2}$, no more viable cells were detectable, a result that is simi-

Volume 5, Issue 1, 2015 

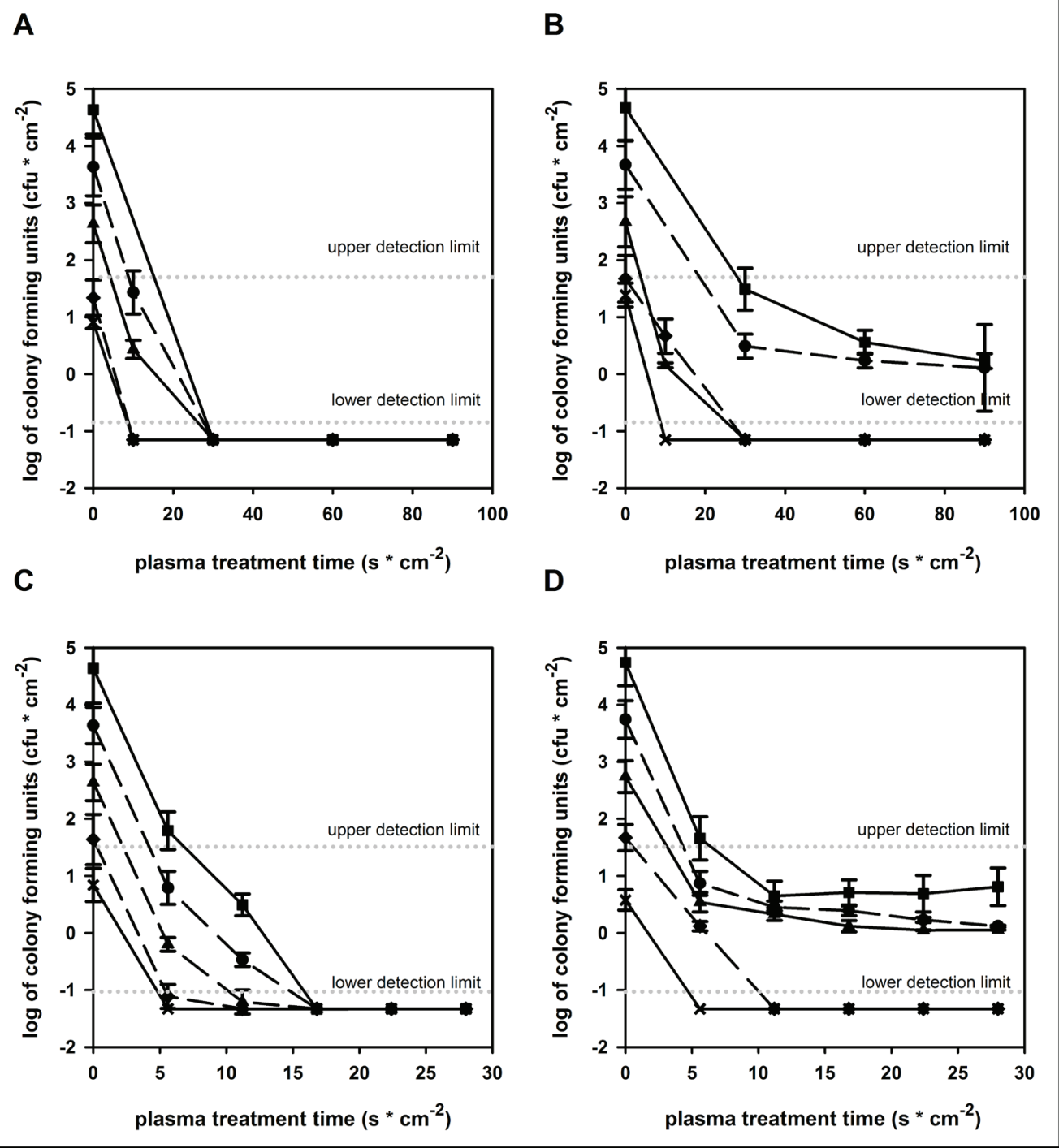

FIG. 5: Inactivation kinetics of $C$. albicans on agar plates as a result of different plasma treatments. (A) Exponentially grown $C$. albicans treated with surface DBD. (B) Stationary grown C. albicans treated with surface DBD. (C) Exponentially grown C. albicans treated with kINPen MED. (D) Stationary grown C. albicans treated with kINPen MED. Average data of three independent tests were used.

lar to the one found with a surface DBD treatment of exponentially grown E. coli K-12 (see Figure 3A). For stationary grown C. albicans seeded in a low initial concentration, the number of viable microorganisms fell below detection limits after a 5,30 , or $60 \mathrm{sec}-\mathrm{cm}^{-2}$ treatment (Figure 5A). Using higher initial concentrations, 
approximately $50 \mathrm{CFU}-\mathrm{cm}^{-2}$ remained viable even after the maximum treatment time of $90 \mathrm{sec}-\mathrm{cm}^{-2}$.

When kINPen MED was chosen for plasma treatment of exponentially grown C. albicans, a rapid decrease of viable cells was detected (Figure 5C). Depending on the initial concentration, no viable cells were found after a 5.6, 11.2, or $16.8 \mathrm{sec}-\mathrm{cm}^{-2}$ treatment time. This corresponds to maximum reduction rates of $2-4.5 \log _{10}$ within $16.8 \mathrm{sec}-\mathrm{cm}^{-2}$. In contrast, treatment of stationary grown C. albicans (Figure 5D) caused a less intense inactivation effect. In two experimental series, numbers of viable cells fell below detection limits after 5.6 and $11.2 \mathrm{sec}-\mathrm{cm}^{-2}$ treatment times when lower initial concentrations were used. For higher initial concentrations, a steep decrease of $2-3 \log _{10}$ per $\mathrm{cm}^{-2}$ was observed. Subsequently, a flattening of the inactivation kinetics profile was found, resulting in 50-100 CFU- $\mathrm{cm}^{-2}$ surviving cells after the maximum treatment time of $28 \mathrm{sec}-\mathrm{cm}^{-2}$. This result was similar to the one found for the kINPen MED treatment of stationary grown $E$. coli $\mathrm{K}-12$ and S. aureus.

\section{DISCUSSION}

\section{A. Growth behavior}

To develop an evaluation method of microbial inactivation experiments in vitro that offers a high degree of comparability (which is not only true for the comparison of plasma sources), the growth behavior of tested strains has to be determined exactly. In our study, the typical phases of growth were obtained for all three microbial test strains (Figure 2): a short lag phase was replaced by an exponential growth phase. ${ }^{22}$ Subsequently, the stationary phase, which might have a range from a few hours to several years, ${ }^{23,24}$ was replaced by a death phase, which marks the end of growth. In the present case, S. aureus and $E$. coli $\mathrm{K}-12$ showed a more rapid change into the growth phases than $C$. albicans. It is already known that $S$. aureus and E. coli K-12 grow faster in batch cultures and thus have a lower doubling time (see Table 2, appendix) than C. albicans. ${ }^{25-27}$ Furthermore, C. albicans shows a longer lag phase than the two other strains. This could be explained by the fact that the lag phase is characterized as an adaption phase; microorganisms need time to adapt to new environmental conditions before starting exponential cell division. ${ }^{22}$ Different research groups showed that eukaryotes, such as C. albicans, and prokaryotes, such as bacteria, translate completely different genes involved in cell growth during the early lag phase. ${ }^{23,28}$ Furthermore, Rolfe et al. 2012 reported that aging process in eukaryotic cells differs from prokaryotic cells. ${ }^{23}$ In general, bacterial cells from the stationary phase representing the end of bacterial life are used for inoculating a batch culture to observe a growth curve. The inoculum is a mixture of damaged and healthy cells, and it correlates with the typical aging process. The key difference in the aging process of prokaryotes and eukaryotes is the reversible growth mechanism only found in prokaryotes. Inoculated prokaryotes are able to initiate rapid cell division because of their quick repair of oxidative damages. Moreover, Rolfe et al. 2012 found in bacteria different intracellular macromolecules, which are essential for an optimal growth. ${ }^{23}$ Yet,

Volume 5, Issue 1, 2015 
such mechanisms are not found in eukaryotic microorganisms. This illustrates why the examined bacterial strains in our study showed a much shorter lag phase and therefore faster growth than the yeast strain. The results showed that both bacterial strains and the yeast are usable for a comparison of antimicrobial effectiveness of various atmospheric plasma sources. However, it has to be taken into account that different microorganisms do not reach the favored growth phase at the same time. The stationary growth phase offers a good basis to test different variables in experimental setups because of its length and homogeneity in cell status. In this phase, the balance of microbial division and death is almost identical. Therefore, we suggest an analysis of microorganisms from a stationary growth phase to ensure a stable and reproducible experimental setup.

\section{B. Plasma inactivation of viable microorganisms}

It is already known that the microbial inactivation effect of different atmospheric pressure plasma sources is based on the production of reactive nitrogen species (RNS) and reactive oxygen species (ROS) ${ }^{10,29-31}$ In the case of the tested plasma sources here, the main RNS are identified as nitrite $\left(\mathrm{NO}_{2}^{-}\right)$, nitrate $\left(\mathrm{NO}_{3}^{-}\right)$, and peroxynitrite $\left(\mathrm{ONOO}^{-}\right)$; and the main ROS is i hydrogen peroxide $\left(\mathrm{H}_{2} \mathrm{O}_{2}\right)$, generated in or transferred into plas-

ma-treated liquids. ${ }^{10,12}$ Furthermore, the production of reactive species results in an acidification of liquids and culture media. ${ }^{11,32,33}$ In combination with an acidification of treated culture medium, the main reactive species $\mathrm{NO}_{2}^{-}, \mathrm{NO}_{3}^{-}, \mathrm{ONOO}^{-}$, and $\mathrm{H}_{2} \mathrm{O}_{2}$ can act as starting reaction partners for the generation of secondary reactive chemical species. The surface DBD produces such substances, which were identified as $\mathrm{NO}^{\bullet}, \mathrm{HO}^{\bullet}, \mathrm{NO}_{2}{ }_{2}$, or different hydroxyl radicals $\left(\mathrm{HOO}^{\bullet}\right)$. They have an antimicrobial effectiveness. ${ }^{20}$ Furthermore, a lot of other reactive species are identified resulting from atmospheric pressure plasma sources, which work under ambient air conditions: ozone $\left(\mathrm{O}_{3}\right)$, superoxide $\left(\mathrm{O}_{2} \bullet^{-}\right)$and peroxide $\left(\mathrm{O}_{2}{ }^{-2}\right) \cdot^{30,34-36}$ These reactive species are mainly products of the reactions between electrons and oxygen or nitrogen. It is known that reactive species have the ability to destroy macromolecules such as DNA, proteins, or lipids. ${ }^{37}$ Hence, the reactive species can enter the cell and destroy lipoproteins and lipopolysaccharide. This process leads to an irreversible inactivation of the microorganisms ${ }^{38}$ In the experiments presented here, the microorganisms had been treated in a humid atmosphere directly on agar surfaces and not in a liquid media. Even though all the processes described earlier had been investigated in bulk liquids, it can be assumed that similar processes and reaction chains based on ROS and RNS also occur in a humid environment. These experiments are the first to compare the antimicrobial properties of plasma sources with such different working methods (spot-like vs. surface treatment). On the one hand, a fixed area is treated step by step at different times. On the other hand, we have the fixed and ring-like area treated by DBD. Here, the problem also offers the solution: by defining a unit area of $1 \mathrm{~cm}^{2}$ for normalization, the microbial results obtained by the used plasma sources can be compared. This procedure allows a direct comparison of both plasma sources, which demonstrates a reasonable compromise for the comparison of different sources working in different modes and treating different sample sizes. 
In the present case, the kINPen MED shows a tendency of faster or more intensive microbial reduction effectiveness than the surface DBD, because these two plasma sources work with different gas systems. The kINPen MED works with argon, an inert plasma-forming gas. Therefore, further metastable argon molecules can be detected in the gas phase, which are classified as reactive species. ${ }^{41}$ Moreover, the use of argon leads to the formation of vacuum ultraviolet (VUV) photons in the range of $115-200 \mathrm{~nm} .{ }^{39}$ The VUV photons interact with the molecules in the gas phase of the generated plasma. These interactions contribute to the generation of reactive species, which have strong antimicrobial activity ${ }^{40,41}$ In contrast, the surface DBD works with ambient air, which does not form VUV photons. In addition, the use of argon leads to a certain amount of residual gas humidity in APPJ. Therefore, a high amount of atomic oxygen $\left(\mathrm{O}\right.$ or $\mathrm{O}^{\bullet}$ ) is produced in the nozzle of the kINPen MED. ${ }^{36}$ Atomic oxygen radicals are one of the most active oxygen species. They have a very high oxidation effectiveness, which is characterized by a rapid inactivation of microorganisms. This results in destruction of peptidoglycans, which in turn damages the microbial cell wall. ${ }^{42}$

In summary, the kINPen MED shows more intensive microbial reduction effectiveness compared to the planar surface DBD treatment. However, this is true if the effectiveness is normalized to $1 \mathrm{~cm}^{2}$, as was done in this study. The practical effectiveness is strongly dependent on the treated area. Under special conditions, e.g. for larger areas, which are covered completely by the electrode area, a treatment with the surface DBD is advantageous. Since the APPJ has a spot-like treatment, the bigger the surface area, the longer the surface-scanning process takes. Against this backdrop, one advantage is that by this way the treated area can be strongly restricted. Consequently, assessment of antimicrobial activity normalized to $1 \mathrm{~cm}^{2}$ is a useful reference method to evaluate the in vitro results of different plasma sources at atmospheric pressures. However, the information about the individual performance characteristics of the tested plasma source is a crucial information for the in vitro characterization of the experiments. Furthermore, other studies have already shown that atmospheric pressure plasma exposure enhanced the inactivation of different kinds of microorganisms, such as gram-positive and gram-negative bacteria, aerobic and anaerobic bacteria, yeasts, endospores and even viruses. ${ }^{4-47}$ This was also demonstrated with the kINPen MED and surface DBD used in this study. ${ }^{10,16,19}$ The results of this study confirm those of previously published experiments. Comparing different microbial strains, we observed that a standardized plasma treatment leads to divergent results. For example, C. albicans and E.coli K-12 showed a faster inactivation rate than the bacterial strain $S$. aureus. As described in the literature, it would be expected that the yeast $C$. albicans is more robust against plasma treatment than the bacterial strains. ${ }^{48}$ Yeasts, like bakers yeasts, are eukaryotic cells, which are similar to mammalian cells. They are highly tolerant to physical stresses because they have a broad repertoire of responses to external stress factors. Together, these responses have protective and restorative functions. ${ }^{49}$ Therefore, it is considered that $C$. albicans is more robust against plasma treatment than the bacterial strains, although other authors found the opposite result. ${ }^{19}$ The high sensitivity of $C$. albicans against the plasma treat-

Volume 5, Issue 1, 2015 
ment could be explained by the physical composition of plasma. Temperature effects and UV radiation (UV-C at around $254 \mathrm{~nm}$ ) can be widely excluded. ${ }^{12,19}$ Another option is the effect of $\mathrm{OH}$ radicals, which are produced by plasma. These radicals in combination with other reactive species are the most lethal elements of plasma to living microorganisms. ${ }^{19}$ Therefore, C. albicans is assumed to be more robust against physical influences (e.g., shear forces) but not against physical plasma effects, which is in constrast to the bacterial strains. For this purpose, proof of a broad spectrum of representative microorganisms is generally necessary for the in vitro characterization of different medical plasma sources. The inactivation effects differ, depending on the microorganism. Furthermore, the reason for different inactivation times between two different bacterial strains could lie in the different cell wall structure. $S$. aureus is a gram-positive bacterium, whereas $E$. coli is a gram-negative bacterium. Most gram-positive bacteria, like $S$. aureus, can survive intense physical influences. For example, gram-positive bacteria are used in the food industry as probiotic cultures in yogurts or are necessary for the production of fermented milk products. ${ }^{50}$ Hence, these bacteria have the ability to survive acidic environments of $\mathrm{pH} 4.0$ or lower. In addition, it is known that cell walls of gram-positive bacteria are more resistant to physical influences, because they have a thicker peptidoglycan layer and teichoic acids. The robust cell wall of gram-positive bacteria also allows applications in bioreactors with strong shear forces. ${ }^{51}$ In general, it is more challenging to inactivate gram-positive bacteria than gram-negative bacteria, including by a treatment with a nonthermal plasma. ${ }^{52,53}$ In terms of the described differences, the tested microorganisms offer a broad spectrum of physiologic cell behavior against external stress such as a plasma treatment. Therefore, these strains are a versatile tool for the characterization of plasma sources, which are used in life science and for medical applications. The in vitro experiments discussed here used microorganisms that are easily and safely managed. Neither challenging and expensive laboratory equipment nor strict safety arrangements are required.

Moreover, the data of this study show that the treatment of exponentially grown microorganisms results generally in faster inactivation kinetics than the treatment of stationary grown cells (Figure 4-6). Nevertheless, these experiments reveal that the growth phase influences the plasma sensitivity of microorganisms. During the stationary growth phase, different enzymes, such as catalase or alkyl hydroperoxidase, are upregulated. With these enzymes, the cells are more protected against physical and chemical influences. ${ }^{54}$ Furthermore, Ponniah et al. ${ }^{55}$ reported that bacteria in the exponential growth phase are more sensitive to physical influences than in the stationary growth phase. Exponential bacterial growth is characterized by bacterial growth in combination with DNA synthesis. In addition, transcription and translation is needed for the synthesis of the necessary macromolecules. ${ }^{23}$ This process causes a certain stress in bacteria leading to more pronounced sensitivity to plasma treatment. Our experimental study showed that not only the type of microorganism but also its phase of growth influences the results. Therefore, we recommend that microorganisms from a stationary phase be used in further studies. Due to the length of the stationary phase compared to the exponential 
growth phase, this constellation ensures a much more reproducible experimental setup with slow and stable inactivation kinetics and therefore an enhanced comparability. Slow inactivation kinetics offers a good basis to test different variables in various experimental setups. With fast inactivation kinetics, differences are much more difficult to detect. The completed cell division leads to a higher uniformity of different microorganisms in the stationary growth phase, leading to a better comparability.

To sum up, a uniform standardized protocol is necessary for characterizing the antimicrobial activity of different atmospheric pressure plasma sources. A standardized approach will enhance the comparability of the vast number of microbial inactivation results in literature.

\section{CONCLUSION}

This study describes the development of a biological reference protocol for the in vitro comparison of the antimicrobial capacity of different atmospheric pressure plasma sources. The following basic criteria for performance characterization in vitro should be helpful to enhance comparison of different plasma sources:

1. Normalization on a treatment area of $1 \mathrm{~cm}^{2}$ to compare different plasma sources that need different modes to treat large areas.

2. Examination of diverse species, which represent reference strains of the entire spectrum of medically relevant microorganisms: a yeast (e.g., C. albicans), a gram-positive bacterium (e.g., S. aureus), and a gram-negative bacterium (e.g., E. coli).

3. Analysis and presentation of different microbial densities per treated area, because inactivation kinetics vary with density.

4. Analysis of microorganisms from a stationary growth phase to ensure a reproducible experimental setup with slow and stable inactivation kinetics. The length of the stationary growth phase and slow inactivation kinetics offer a good basis to test different variables in experimental setups.

5. Definition of detection limits of $1-350 \mathrm{CFU}$ per treated area to minimize counting and mathematical errors.

\section{ACKNOWLEDGEMENT}

The authors thank Mrs. Kristin Loyal at the INP Greifswald e. V. for excellent technical assistance. The authors also thank Dr. Christine Pöhlke for splendid language assistance. Furthermore, the authors thank the German Federal Ministry of Economics and Technology, (Grant no. 01FS12001) for financial support.

Volume 5, Issue 1, 2015 


\section{REFERENCES}

1. Debus ES, Winkler M, Larena-Avellaneda A, Bültemann A, Daum H, Lingenfelder M, Schulenburg B, Gross-Fengels W. Medizinische und ökonomische aspekte der Zentrumsbildung in der wundbehandlung. Gefäßchirugie. 2003;8:259-68.

2. Lauterbach S. Chronische Wunden - Ulcus cruris, diabetisches Fußsydrom, Dekubitus, Verbrennungen. PZ Prisma. 2006:4;239-44.

3. Lloyd G, Friedman G, Jafri S, Schultz G, Fridman A, K. Harding K. Gas plasma: medical uses and developments in wound care. Plasma Process Polym. 2010;7:194-211.

4. Weltmann K-D, von Woedtke T. Basic requirements for plasma sources in medicine. Eur Phys J Appl Phys. 2011;55:13807.

5. Einsiedel T, Bischoff M, Kolodziej S, Vogel M, Kinzl L, Schmelz A. Aktueller Stand der Wundbehandlung - ein Überblick. klinikarzt. 2004;33(8/9):239-45.

6. Stoffels E., Flikweert A. J., Stoffels W. W. and Kroesen G. M. W. (2002). Plasma needle: a non-destructive atmospheric plasma source for fine surface treatment of (bio)materials. Plasma Sources Sci. Technol. 11, 4

7. Kuchenbecker M., Bibinov N., Kaemling A., Wandke D., Awakowicz P. and Viöl W. (2009). Characterization of DBD plasma source for biomedical applications. J. Phys. D. Appl. Phys. 42, 045212

8. Rupf S, Lehmann A, Hanning M, Schäfer B, Schubert A, Feldmann U, Schindler A. Killing of adherent oral microbes by a non-thermal atmospheric plasma jet. J Med Microbiol. 2010;59(2):206-12.

9. Weltmann K-D, Kindel E, von Woedtke T, M. Hähnel M, M. Stieber M, Brandenburg R. (2010). Atmospheric-pressure plasma sources: prospective tools for plasma medicine. Pure Appl Chem. 2010;82(6):1223-37.

10. Oehmigen K, Winter J, Hähnel M, Wilke C, Brandenburg R, Weltmann K-D, von Woedtke T. Estimation of possible mechanisms of Escherichia coli inactivation by plasma treated sodium chloride solution. Plasma Process Polym. 2011;8:904-13.

11. Oehmigen K, Hähnel M, Brandenburg R, Wilke C, Weltmann K-D, von Woedtke T. The role of acidification for antimicrobial activity of atmospheric pressure plasma in liquids. Plasma Process Polym. 2010;7(3-4)250-7.

12. Weltmann K-D, Kindel E, Brandenburg R, Meyer C, Bussiahn R, Wilke C, von Woedtke T. Atmospheric pressure plasma jet for medical therapy: plasma parameters and risk estimation. Contrib Plasma Phys. 2009;49(9):631-40.

13. Metelmann H-R, von Woedtke T, RBussiahn R, Weltmann K-D, Rieck M, Khalili R, Podmelle F, Waite PD. (2012). Experimental recovery of $\mathrm{CO}_{2}$-laser skin lesions by plasma stimulation. Am J Cosmet Surg. 2012;29(1):52-6.

14. Metelmann H-R, Vu TT, Do HT, Le TNB, Hoang THA, Phi TTT, Luong TML, Doan VT, Nguyen TTH, Nguyen THM, Le DQ, Le TKX, von Woedtke T, Bussiahn R, Weltmann K-D, Khalili R, Podmelle F. Scar formation of laser skin lesions after cold atmospheric pressure plasma (CAP) treatment: a clinical long term observation. Clin Plasma Med. 2013;1(1):30-5.

15. Bussiahn R, Lembke N, Gesche R, von Woedtke T, Weltmann K-D. Plasma sources for biomedical applications. Hyg Med. 2013;38:212-6.

16. Daeschlein G, von Woedtke T, Kindel E, Brandenburg R, Weltmann K-D, Jünger M. Antibacterial activity of an atmospheric pressure plasma jet against relevant wound pathogens in vitro on a simulated wound environment. Plasma Process Polym. 2010;7:224-30. 
17. Daeschlein G, Scholz S, Arnold A, Svon Podewils S, Haase H, Emmert S, von Woedtke T, Weltmann K-D, Jünger M. In vitro susceptibility of important skin and wound pathogens against low temperature atmospheric pressure plasma jet (APPJ) and dielectric barrier discharge plasma (DBD). Plasma Process Polym. 2012;9:380-9.

18. Daeschlein G, Napp M, von Podewils S, Lutze S, Emmert S, Lange A, Klare I, Haase H, Gümbel D, von Woedtke T, Jünger M. (2014). In vitro susceptibility of multidrug resistant skin and wound pathogens against low temperature atmospheric pressure plasma jet (APPJ) and dielectric barrier discharge plasma (DBD). Plasma Process Polym. 2014;11:175-83.

19. Daeschlein G, Scholz S, von Woedtke T, Niggemeier M, Kindel E, Brandenburg R, Weltmann K-D, Juenger M. (2011). In vitro killing of clinical fungal strains by low-temperature atmospheric-pressure plasma jet. IEEE Trans Plasma Sci. 2011;39(2):815-21.

20. Hähnel M, Brüser V, Kersten H. (2007). Diagnostics of SiOx-containing layers deposited on powder particles by dielectric barrier discharge. Plasma Process Polym. 2007;4:629-37.

21. Hähnel M, von Woedtke T, Weltmann K-D. Influence of the air humidity on the reduction of Bacillus spores in a defined environment at atmospheric pressure using a dielectric barrier surface discharge. Plasma Process Polym. 2010;7:244-9.

22. Madigan MT, Martinko JM, Parker J. Brock biology of microorganisms. Upper Saddle River, NJ: Prentice-Hall; 2000. p 135-62.

23. Rolfe MD, Rice CJ, Lucchini S, Pin C, Thompson A, Cameron ADS, Alston M, Stringer MF, Betts RP, Baranyi J, Peck MW, Hinton JCD. Lag phase is a distinct growth phase that prepares bacteria for exponential growth and involves transient metal accumulation. $J$ Bacteriol. 2012;194(3):686-701.

24. Finkel SE. Long-term survival during stationary phase: evolution and the GASP phenotype. Nat Rev Microbiol. 2006;4:113-20.

25. Kazempour ZB, Yazdi MH, Rafii F, Shahverdi AR.Sub-inhibitory concentration of biogenic selenium nanoparticles lacks post antifungal effect for Aspergillus niger and Candida albicans and stimulates the growth of Aspergillus niger. Iran J Microbiol. 2013;5(1);81-5.

26. Hirsch-Kauffmann M, Schweiger M. Biologie für mediziner und naturwissenschaftler. 6th ed. Stuttgart: Thieme; 2006.

27. Sutherland R, Rolinson GN. Characteristics of methicillin-resistant staphylococci. J. Bacteriol. 1964;87(4):887-99.

28. Brejning J, Jespersen L, Arneborg N. Genome-wide transcriptional changes during the lag phase of Saccharomyces cerevisiae. Arch Microbiol. 2003;79:278-94.

29. Kogelschatz U. Dielectric-barrier discharges: their history, discharge physics, and industrial applications. Plasma Chem Plasma Process. 2003;23(1):1-46.

30. van Gils CAJ, Hofmann S, Boekema BKHL, Brandenburg R, Bruggeman PJ. Mechanisms of bacterial inactivation in the liquid phase induced by a remote RF cold atmospheric pressure plasma jet. $J$ Phys D: Appl Phys. 2013;46(17):175203.

31. Graves DB. The emerging role of reactive oxygen and nitrogen species in redox biology and some implications for plasma applications to medicine and biology. J Phys D: Appl Phys. 2012;45:263001.

32. Doubla A, Bouba Bello L, Fotso M, Brisset J-L. Plasmachemical decolourisation of bromothymol blue by gliding electric discharge at atmospheric pressure. Dyes Pigm. 2008;77(1):118-24.

Volume 5, Issue 1, 2015 
33. Marouf-Khelifa K, Abdelmalek F, Khelifa A, Belhadj M, Addou A, Brisset J-L. Reduction of nitrite by sulfamic acid and sodium azide from aqueous solutions treated by gliding arc discharge. Sep Purif Technol. 2006;50(3):373-9.

34. Winter J, Duennbier M, Schmidt-Bleker A, Meshchanov A, Reuter S, Weltmann K-D. Aspects of UV-absorption spectroscopy on ozone in effluents of plasma jets operated in air. J Phys D: Appl Phys. 2012;45(38):385201.

35. Gaunt LF, Beggs CB, Georghiou GE. Bacterial action of the reactive species produced by gas-discharge nonthermal plasma at atmospheric pressure: a review. IEEE Trans Plasma Sci. 2006;34(4):1257-69.

36. Reuter S, Winter J, Schmidt-Bleker A, Schroeder D, Lange H, Knake N, Schulz-von der Gathen V, Weltmann K-D. Atomic oxygen in a cold argon plasma jet: TALIF spectroscopy in ambient air with modelling and measurements of ambient species diffusion. Plasma Sources Sci Technol. 2012;21(2):024005.

37. Cabiscol E, Tamarit J, Ros J. Oxidative stress in bacteria and protein damage by reactive oxygen species. Int Microbiol. 2000;3(1):3-8.

38. Sohbatzadeh F, Colagar AH, Mirzanejhad S, Mahmodi S. E. coli, P. aeruginosa, and B. cereus bacteria sterilization using afterglow of non-thermal plasma at atmospheric pressure. Appl Biochem Biotechnol. 2010;160(7):1978-84.

39. Lange H, Foest R, Schäfer J, Weltmann K-D. Vacuum UV radiation of a plasma jet operated with rare gases at atmospheric pressure. IEEE Trans Plasma Sci. 2009;37(6):859-65.

40. Schneider S, Lackmann J-W, Ellerweg D, Denis B, Narberhaus F, Bandow JE, Benedikt $\mathrm{J}$. The role of VUV radiation in the inactivation of bacteria with an atmospheric pressure plasma jet. Plasma Process Polym. 2012;9(6):561-8.

41. Singh MK, Ogino A, Nagatsu M. Inactivation factors of spore-forming bacteria using lowpressure microwave plasmas in an $\mathrm{N}_{2}$ and $\mathrm{O}_{2}$ gas mixture. New J Phys. 2009;11:115027.

42. Yusupov M, Neyts EC, Khalilov U, Snoeckx R, van Duin ACT, Bogaerts A. Atomic-scale simulations of reactive oxygen plasma species interacting with bacterial cell walls. New J Phys. 2012;14:093043.

43. Schnabel U, Niquet R, Krohmann U, Polak M, Schlüter O, Weltmann K-D, Ehlbeck J. Decontamination of microbiologically contaminated seeds by microwave driven discharge processed gas. J Agricult Sci Appl. 2012;1(4):100-6.

44. Maisch T, Shimizu T, Li Y-F, Heinlich J, Karrer S, Morfill G, Zimmermann JL. Decolonisation of MRSA, S. aureus and E. coli by cold-atmospheric plasma using a porcine skin model in vitro. PLoS One. 2012;7(4):1-9.

45. Kvam E, Davis B, Mondello F, Garner AL. Nonthermal atmospheric plasma rapidly disinfects multidrug-resistant microbes by including cell surface damage. Antimicrob Agents Chemother. 2012;56(4):2028-36.

46. Moreau M, Orange N, Feuilloley MGJ. Non-thermal plasma technologies: new tools for biodecontamination. Biotech Adv. 2008;26:610-7.

47. Kelly-Wintenberg K, Hodge A, Montie TC, Deleanu L, Sherman D, Roth JR, Tsai P, Wadsworth L. Use of a one atmosphere uniform glow discharge plasma to kill a broad spectrum of microorganisms. J Vac Sci Technol A Vac Surf Films. 1999;17(4):1539-44. 
48. Klämpfl TG, Isbary G, Shimizu T, Li Y-F, Zimmermann JL, Stolz W, Schlegel J, Morfill GE, Schmidt H-U. Cold atmospheric air plasma sterilization against spores and other microorganisms of clinical interest. Appl Environ Microbiol. 2012;78(15):5077-82.

49. Attfield PV. Stress tolerance: the key to effective strains of industrial baker's yeast. Nat Biotechnol. 1997;15:1351-7.

50. Cotter PD, Hill C. Surviving the acid test: responses of gram-positive bacteria to low $\mathrm{pH}$. Microbiol Mol Biol Rev. 2003;67(3):429-53.

51. Park SJ, Cochran JR. Protein engineering and design. Boca Raton, FL: CRC Press; 2010. p. 29.

52. Ermolaeva SA, Varfolomeev AF, Chernukha MY, Yurov DS, Vasiliev MM, Kaminskaya AA, Moisenovich MM, Romanova JM, Murashev AN, Selezneva II, Shimizu T, Sysolyatina EV, Shaginyan IA, Petrov OF, Mayevsky EI, Fortov VE, Morfill GE, Naroditsky BS, and A. L. Gintsburg AL. Bactericidal effects of non-thermal argon plasma in vitro, in biofilms and in the animal model of infected wounds. J Med Microbiol. 2011;60:75-83.

53. Zhang J. Sterilization of bacterial spores using supercritical carbon dioxide. UMI Number: 3232556; Ann Arbor, MI. ProQuest Information and Learning Company; 2006. p. 11.

54. Heuner K, Swanson M. Legionella: molecular microbiology. Norfolk, UK: Caister Academic Press; 2008. p. 57.

55. Ponniah G, Chen H, Michielutti R, Salonen N, Blum P. Single-cell protein profiling of wastewater enterobacterial communities predicts disinfection efficiency. Appl Environ Microbiol. 2003;69:4227-35.

Volume 5, Issue 1, 2015 